\title{
Activities of the Society
}

\author{
The 33rd Annual Meeting of \\ The Electrochemical Society of Japan
}

\author{
Waseda University, Tokyo \\ April 5, 6, 7 and 8, 1966 \\ SCHEDULE
}

$\begin{array}{ll}\text { Tuesday, April 5, 1966, } 9.00 \text { a.m. - 4.20 p.m. } & \text { Conferences and Invited Lectures } \\ \text { Wednesday, April 6, 1966, } 9.00 \text { a.m. - 5.00 p.m. Conferences } \\ \text { Thursday, April 7, 1966, } 9.00 \text { a.m. - } & \text { Excursion } \\ \text { Friday, April 8, } 1966 & \text { Excursion }\end{array}$

\section{CONDENSED PROGRAM}

\section{Tuesday, April 5, 1966}

Theoretical Electro-chemistry and Applied Physical Chemistry (A $101-A$ 121)

9.00 a.m. -4.15 p.m.

Electroorganic (B 101 - B 109) 9.00 a.m. - 11.20 a.m.

Electro-Analysis (B 110) 11.20 a.m. - 11.35 a.m.

Electro-deposition and Surface Treatment (B 111 - B 121) 11.35 a.m. - 12.10 p.m. Battery (C. 101 - C 121) 9.00 a.m. - 4.20 p.m.

\section{Wednesday, April 6, 1966}

Theoretical Electro-chemistry and Applied Physical Chemistry (A 201 - A 203)

$$
9.00 \text { a.m. - } 11.30 \text { a.m. }
$$

Industrial Electrolytic ( A 209 - A 213) 11.30 a.m. - 1.55 p.m.

Corrosion and Anti-corrosion (A 214 - A 222) 1.55 p.m. - 4.55 p.m.

Electro-deposition and Surface Treatment (B 201 - B 204) 9.00 a.m. - 10.20 a.m.

Extractive Metallurgy (B 205 - B 211) 10.20 a.m. - 1.45 p.m.

High Temperature Chemistry and Fused Salts (B 212 - B 220) 1.45 p.m. - 4.55 p.m. Battery (C 201 - C 206) 9.00 a.m. - 11.10 p.m.

Electronics and Materials for Electrical Industry (C 207 - C 222)

11.10 a.m. - 4.50 p.m. 


\section{Program-The 33rd Annual Meeting}

\section{Theoretical Electro-Chemistry and Applied Physical Chemistry}

A 101 The System $\mathrm{NaIO}_{3}-\mathrm{HIO}_{3}-\mathrm{H}_{2} \mathrm{O}$ at $15^{\circ} \mathrm{C}$, Tetsuro $\mathrm{W}_{\mathrm{ATANOBE}}$ and MORIOKI SHIBUYA

A 102 Methods of Representation for Phase Diagram of Multi-Component Systems, MотоYUKI TAKEI

A 103 Activity of $\mathrm{NaOH}$ in $\mathrm{Na}_{2} \mathrm{CO}_{3}$ aqueous Solution, Shiro Yoshizawa, Fumio HINE, YASUMI KAMINO and MASAA K I MIYA J I

A 104 Studies of the dissociation of Perchlorate by Raman Spectros Copy, Tokuzo Tonomura and TomoSHIGE MORITA

A 105 Measurement of Ion Concentration in the Diffusion Layer by the Infrared Multiple Reflection Method, TSUTOMU TAKAMURA

A 106 A Study of Dipole Moment by Raising the Temperature, YUICHI KAMURA and HIROKU MIHARA

A 107 Study on the Specific Phenomenon in the Polarization of High-Pressure Gases. II, YUICHI KAMURA and EIKO OGURA

A 108 Fundamental Study on the Vapor Growth of GaAs. I. On the System Ga- $\mathrm{I}_{2}$, KотARо UChimuRA, ToShio Kunugi, Toru Murakami and HIDEAK I FU JISA w A

A 109 Fundamental Study on the Vapor Growth of GaAs. I. On the System As-I ${ }_{2}$ Kotaro UCilimura, ToShio Kunugi, Toru Murakami and HIDEAKI FUJISA W A

A 110 Study on the System of Si-I, $\mathrm{KO}$ taro Uchimura, Toshio KuNUGi, TORU MURAKAMI and HIDEAKI FUJISAWA
A 111 The Specific Adsorption of Coumarin on the Mercury Interface, Is AO SEkine, Yoshiniko MatsuMOTO and TADASHI YOSHIDA A 112 Adsorption and Desorption Velocity of Hydrogen of the Evaporated Platinum Electrode, HISASHI SHIM I Z U

A 113 A Study of the Adsorption of $\mathrm{HCN}$ on Electrodes from Solution, KL A U S MÜ L LE R

A 114 Electrode Potential of $\mathrm{Pt}$ in the Electrolyte Containing the Surface Active Agent, TADAO KA TO, HIDEO ONOUE and TAKEO MATSU$\mathrm{NO}$

A 115 Photo-Electrochemical Reaction on Zinc Oxide Electrode, Nilmura TAKEO, KENICHI HONDA and SHIN'ICHI KIK U C H I

A 116 Study of Photovoltaic Effect with a Platunum Electrode, $\mathrm{K}_{\mathrm{ENICHI}}$ HONDA, TAKASHI YURA and SHINICHI KIK U C HI

A 117 Surface Relaxation Effect on Germanium Electrode, SHinobu ToSHIMA and ISAMU UCHIDA

A 118 Characteristics of Surface Impedance on Oxide Films, SHINOBU TOSHIMA, ISAMU UCHIDA and TAKA K I SA KA MOTO

A 119 Electrode Processes by Tunnelling of Electrons, AKIKO ARAMATA

A 120 Periodic Variation of Exchange Current Density of Hydrogen Electrode Reaction with Atomic Number and Reaction Mechanism, HIDEAKI KIT A

A 121 Theory of Potentiostatic and Galvanostatic Charging of the Double Layer in Electrodes, TAKASHI MOROZUMI

A 201 Electrochemical Dissolution of 
Hydrogen of Partially Immersed Platinum Electrodes, SHIRO HARUYAMA and MASAO MUKAI

A 202 Studies of Oxygen Evolution and Reduction at Gold and Silver Electrodes, SHigeo Kondo, Kunio $\mathrm{OHASHI}$ and SHIgEO NAgAU RA

A 203 The Dependence of Cl- Concentration on the $\mathrm{Cl}_{2} / \mathrm{Cl}$ Electrode $\mathrm{Re}$ action on Pt. SHINoBU Toshima and HIROSHI OKANIWA

A 204 The $\mathrm{Cl}_{2} / \mathrm{Cl}^{-}$Electrode Reaction on the Various Electrode Metal, SHINOBU TOSHIMA and HirOSHI OK A N IW A

A 205 Studies on the Chlorine Electrode Reaction by Galvanostatic Method, Shinobu Toshima, Hiroshi OKaniwa, MiZuki Nishijima and KATSUICHI WAKATA

A 206 Studies on the Electrolytic Production of Condensed Phosphoric Acids. $\mathrm{V}, \mathrm{H}_{2}$ and $\mathrm{O}_{2}$ Evolution Reaction in the Electrolytic Condensation of Phosphoric Acid. Munehiko Kuwa, TAKashi SAjI and MASAO MUKAI

A 207 An Electrochemical pCI. Stat and Its Application, TAKASHI MO ROZUMI and HiROSHI OHASHI

A 208 Electrophoretic Separation of Sodium Sulphate and Sulfuric Acid with Bipoler Ion Exchange Membranes, HisASHI KISAKI and KAZUTOMO MIZ UM OT O

\section{Industrial Electrolytic}

A 209 Studies on Platinum Plated Electrodes III, Yoshio Yagi, YuKio FUKUMOTO and TAKEO ISHIDA

A 210 The Anode of Palladium-Platinum Alloys for Brine Electrolysis, OSAmU SUZUKI and Tomio FuKUNAGA

A 211 Mechanism on Electrodeposition of Manganese Dioxide in Acidic Medium, Masatoshi Sugimori and $\mathrm{T}_{\mathrm{A}} \mathrm{RO}$ SEKINE
A 712 Chemical-Engineering Analysis of Electrolytic Cells. IV, Resistance Between Parallel Electrodes, KA OR U KOJIMA

A 213 Dispersion Effect and Shielding Etfect of Gas Bubbles in the Vicinity of Electrode, MASAO TAKAHASHI and TERUMITSU KAWA B A T A

\section{Corrosion and Anti-Corrosion}

A 214 Studies on Corrosion Fatigue by Potential Measurement, YUTAKA Kose, Yoshitsugu Ogawa and HIDEO ODAIRA

A 215 Effect of Sulfur on the Corrosion of Electrodeposited Nickels. II, NA O J I FURUKAWA, TADAO HAYASHI and TAKEO ISHIDA

A 216 The Studies on the Corrosion of the $\mathrm{Pb}-\mathrm{Sb}$ Alloys. II, SA TOShI SEKIDO, SADAO Katoh and MASATARO FUKUDA

A 217 Effect of Anions on the Initiation of Pitting Corrosion of Stainless Steel, Go OKaмото, Tатsuo ISHIK A WA and SHIGERU HAYASHI

A 218 Anodic Passivation of Palladium and Palladium-Platinum Alloys in Aqueous Chloride Solutions, $\mathrm{MA}_{\mathrm{A}}$ SAO TAKAHASHI and YASUSHI $\mathrm{K}_{\mathrm{A}} \mathrm{N}$ Z A K I

A 219 Thermogalvanic Corrosion of Aluminium MORIHIKo OHTA, TOMIYA KISHI, TAKASHI NAgAI and TAKESHI TAKEI

A 220 The Mechanism of the Accelerating Effect of Fluoride Ion for Corrosion of Aluminium, MASAyOSHI KATOH and TOSHIYUKI WATANABE

A 221 Influence of a Chelating Agect (Citric Acid) on the Corrosion of Aluminium, MASA Y OSH I KA TOH

A 222 Inhibitive Effects of Alizarin Derivatives as the Inhibitors of Aluminum in Alkaline Medium, HIROKO MIHARA and YASUMASA $\mathrm{H}_{\mathrm{A}}$ Y A K A W A 


\section{Electroorganic}

B. 101 Mechanism of Kolbe Electrode Process at Various Anode Materials, Norio Sato, Kitchiro Sugino and $\mathrm{T}_{\mathrm{A}} \mathrm{RO} \mathrm{S}_{\mathrm{EK}} \mathrm{INE}$

B 102 Cathodic Reaction of Dailkyl Cyanamides, SHinjI TAKENAKA and TARO SEKINE

B 103 On the Cathodic Reduction Process of Aliphatic Ketons (Especially of Acetone), AKIRA YAMURA, TARO SFIINE and KIICHIRO Sugino

B 104 Preparation of Amines by Electrolytic Reduction of CarbonylAmmonia Addition Compounds, Hiroaki Muto, Eitchi IChikaWA and KEIJIRO ODO

B 105 Solvent Effects in Electrolytic Reduction of Anthraqunone, WATARU SAKaI, Koichiro Kusunoki and KATSuHara MiYata

B 106 Behavior of Platinum Anode in Lauric Acid Solution, $\mathrm{T}_{\mathrm{AKEO}}$ Hisano, Toshio Terazawa and Hiroshi Matsui

B 107 Electrolytic Preparation of OArsanilic Acid, KAzUO YASUKOUchi, Hiroshi Muto, Akimitsu IWANAGA and Noria KI URABE

B 108 Electrolytic Oxidation of Tropyridene. Supplement, JUN MIZUG UCH I and TOSHIO SATO

B 109 Polarography of Phenazines, SETSUKO NAKAMURA and TADASHI YOSHID A

\section{Electro-Analysi s}

B 110 Polarographic Determination of $\mathrm{K}$ and $\mathrm{Na}$ in Sugar, NAOY ASU Iw ASA

\section{Electro-deposition and Surface Treatment}

B 111 Electrodeposition of Copper on the Copper Single Crystal (100) from Copper Perchlorate Bath, SHUN'ICH I HIGUCHI, TADAO HAYASHI and TAKEO ISHIDA
B 112 Effect of Addition Agents on Electrodeposition of Copper. VI. Potential Transition with Time, Hozumi Hutata, Rikuo TomiNAGA, Tetsuro SEIYAma and TAKESHIRO MINE

B 113 Electrodeposition of Copper from Ethylendiamin- $\mathrm{Cu}$ Chelate Bath, SAKAE TAJima, TAKEMI MORI and TESUO SANO

B 114 Influence of 1-Cystine $\left(\mathrm{S}^{35}\right)$ and Some Addition Agents in the Electrodeposition of Copper, HIROShi Kinoshita, TADaO HaYASHI and TAKEO ISHIDA

B 115 The Effects of Addition Agents on the Electrodeposition of Nickel, ISAO SEKINE and TADASHI YOSHID A

B 116 The Effect of Some Addition Agents on Nickel Electrodeposition, ShIRo Yoshizawa, ISAO TARI and MASANORI YOKOYAMA

B 117 Surface Texture of Nickel Electrode in Anodic Corrosion, $\mathrm{T}_{\mathrm{AKA}}$ YASU SHIRASAKI, SHIGEAKI SAKAMOTO and AKIKATSU KITAH A R A

B 118 On the Influence of Valencies of $\mathrm{Sn}$ Ion in the Electrolysis of Tin, TAKeshi TSURUOKA and TomoHiK O ARITA

B 119 Iron-Zinc, Alloy Plating, HISASHI ITo, KeI HigASHI and YoICHI A Z UMA

B 120 Electrodeposition of Aluminium from $\mathrm{AlCl}_{3}-\mathrm{LiAlH}_{4}$-Tetrahydrofran Bath., Yoshimi Hanamura, NoBuHiko Ishibashi and Tetsuro SEIYAMA

B 121 Anodic Oxidations of Aluminium at High Current Densities, MICHIKo SHimura and $\mathrm{S}_{\mathrm{AKAE}} \mathrm{TAJUma}$

B 201 Anodic Oxidation of Aluminum in Sulfuric Acid Electrolytes, SEICHiro Eguchi, Shoichiro Morishima and TAlichiro MANT A N I

B 202 Studies on the Surface Coating by Disproportionation. I. Titanium, 
TAKEHIKO TAKAHASHI, KOZOH Sugiyama and Kensuke Tomita

B 203 On the System for Electrolytic Treatment of Continuous Wire or Strip without Electrodes, NAOMASA FuJise

B 204 Mechanism of Electrodeposition of Water-Soluble Polumers, SHIgeyoshi MaEda, NAOE Hirai, Hideya OKada and Katsura IN OUE

\section{Extractive Metallurgy}

B 205 Reduction of Microfine Powder of Ferric Oxide by Various Gases in Fluidized Bed, KoEmon FUNAKI, YASUO TSUKUDA and YoshiY UKI NAKAMURA

B 206 Some Observations on Lead Compound, Hisashi Ito, TSUTOMU YANAGASE and MAMORU YOSHINA G A

B 207 Electrolytic Reduction Process of Niobium Tritaoctachloride, TA D SHI SUZuki and Yuzo SAEKI

B 208 Photolytic Preparation of Uranium. IV. Fluorides, KOEMON FUNAKI, ITARU IshiJima and MASAmI $\mathrm{S}_{\mathrm{A} \text { ITO }}$

B 209 On the Dephosphorization of High Silicon-Ferroalloy, ISAO TANABE, ShOzO TAKASE and TSUnEyoSHI INAMI

B 210 Decarburization of High Carbon Ferrochromium, MASAJU ISHII, Tetsuro Yoshida and Takeshi TAKEI

B 211 Preparation of Molybdenum Nitride by Use of Nitrogen Plasma Jet, OSAmU MATSUmOTO and YASUMASA HAYAKAWA

High Temperature Chemistry and Fused Salts

B 212 Solubility of $\mathrm{Ag}_{2} \mathrm{O}$ in $\mathrm{B}_{2} \mathrm{O}_{3}-\mathrm{Na}_{2} \mathrm{O}$ Molten Oxide Solution, TAKASHI MAEKAWA, TOSHIO YOKOKAWA and KICHIZ O NIWA

B 213 The Electric Conductivity of Fused
Salt, KIYOKADO NishiHARA, TERUO NAKANISHI and YOSHITAKa Matsumura

B 214 Studies on Liquid-State Electronic Elements in a Molten Salt, TAKashi Mukaibo and Syukuji AS A K UR A

B 215 E. M. F. Measurements of Zirconium Dichloride in Fused Sodium Chloride-Potassium Chloride System, Tomiyoshi SAKaKuRA and TOMOO KIRIHARA

B 216 Anodic Reaction on the Molten Lithium Chloride-Potassium Chloride Systems, NoBUATSU WATANABE, Shogo KONO and YoJi OH A R A

B 217 Anode Reaction in Cryolite-Alumina Molten Electrolyte, MASAO $\mathrm{T}_{\mathrm{AKAHASHI}}$ and HIDEAKI MINA$\mathrm{TA}$

B 218 Studies on the Electrometallurgy of Titanium in the Fused Salts. II. Decomposition Potential of $\mathrm{CaCl}_{2}-\mathrm{TiO}_{2}$ System, Rinzo MIdoRIKAWA and KINJI KATO

B 219 Chlorine Evolution Reaction on Platinum Electrode in Molten Chloride, MASAO TAKAHASHI and YASUSHI KAN Z AKI

B 220 Anode Overvoltage in Aluminium Production, Nobuatsu $\mathbb{W}_{\text {A T A N A - }}$ $B E$ and NOBUHIRO OBA

\section{Battery}

C 101 On the Reactivities of Etylene and Propane, IsaO OGINo, SACHIO TAKahashi, Shunji Ninagi and Yoshizo MIYAKE

C 102 The Effect of Electrolytes on the Anodic Oxidation of Methanol, YoshiYUKI TAKADA, SACHIO TAKAHASHi and Yoshizo MiYa $\mathrm{KE}$

C 103 PH Effects of the Electrolyte Solution upon the Anodic Reaction of Methanol, Ryohei Furumi, TSutomu Iwaki and MASataro FUK U D A 
C 104 Studies on the Methanol Fuel Cell. IV. Methanol-Hydrogen Peroxide Fuel Cell, Chiaki IwakuRa, HiDEO TAMURA and Toshio Ishi$\mathrm{NO}$

C 105 Methanol-Air Fuel Cell System, Hironosuke IKEDA, KENICHI TOYODA and TAKASHI SAKAI

C 106 The Anodic Oxidation of Ethanol and Its Substitution Products, SACHIO TAKAHASHI and YoshiZ O MIYAKE

C 107 Hydrazine-O 2 Fuel Cell. VI. Polarization Characteristics of NI-B and Electrode, TADAO $\mathrm{H}_{\mathrm{AYASHI}}$, TAKU AOYAMA and TAKEO ISHID A

C 108 The Study on the Solved Gas Fuel Cell with Liquid Flow Through Electrode. IV, MASAO KUBOKAWA, MASAMICHI Yamashita and HIDE TOSHI ICHINO

C 109 Studies on Redox Fuel Cell. IV. The Regeneration of Catholyte, Shin'ichi Ashimura , Toshio Inoue and Yoshizo Miyake

C 110 Studies on the Cells Using IonExchange Membranes, HIDEO OnOUE, Kenichi TaKeuchi and TAKEO MATSUNO

C 111 Studies on Fuel Cells. IX. Polarization Characteristics of the Metallic Screen Electrode Pressed in Ion-Exchange Membrane, YosHIharu Matsuda, Hideo Tamura and Toshio Ishino

C 112 Studies on Air Electrodes. V. Relation Between Life of Carbon Electrode and Degree of Penetration of Electrolyte into Carbon Electrode, SABURO MAKINO and SEIJI ORISAK U

C 113 Preparation of Porous Carbon Electrodes and Physical Properties of Them, GENTARO KANO and KIY OSHI HORIT A

C 114 Wetproofing of Carbon Electrodes by Fluorine Resin, ROKURO FUJII and YOSHIZO MIYAKE

C 115 Studies on High Temperature Fuel
Cell. VI. The Temperature Fuel Cell with a Pasty Electrolyte, Koichi Shiota, Hideo Tamu$\mathrm{RA}$ and TOSHIO ISHINO

C $116 \mathrm{ZnO}$ System as Cathode Materials of the High Temperature Fuel Cell. II, TAKEHIKO TAKAHASHI, Kaname ITO and Yutaka SuZu$\mathrm{K}$ I

C 117 A New Chlorine-Hydrogen Fuel Cell with Paste-Matrix Electrolyte, Shiro Yoshizawa, Zenichiro TAKEHARA and YOICHI NAKAHA R A

C 118 Studies on Sealed Alkaline Batteries. I. A Reaction Between Cadmium Impregnated in Sintered Nickel Plaques and Gaseous Oxygen, TAKASHI IIJima, SATORU SEKIDO and MASATARO FUKUDA

C 119 Studies on the Pressed-Type Alkaline Storage Batteries. II. Effect of Addition Agents on the Cadmium Negative Plate, DAIJIRO YAMASHITA and Yoshinumi YAMAMOTO

C 120 Study on the Capacity of $\mathrm{Cu}$ $\mathrm{PbO}_{2}$ Storage Battery, SHIN'ICHI Furumi and Toshimichi Kubo

C 121 The Characteristics of $\mathrm{PbCl}_{2}$ as the Solid Electrolyte, SHIN O B U TO SHIMA, YOSHIO NIIZEKI and RY U JI NIK AID O

C 201 On the Potentiostatic Discharge Characteristic of Electrolytic Manganese Dioxide SHUNJI NINAGI Yoshizo MiYaKe

C 202 The Dissolution of $\mathrm{Mn}^{2+}$ Ion on the Discharge Reaction of Manganese Dioxide Electrode, AKIO ERA, $\mathrm{ZEN}_{\text {ENCHRO TAKEHARA }}$ and SHiro Yoshizawa

C 203 The Role of $\mathrm{NH}_{4}^{+}$and $\mathrm{Zn}^{2+}$ Ions on the Discharge Reaction of Manganese Dioxide Electrode, AKIO ERA, ZEN'ICHIRO TAKEHARA and SHIRO YOSHIZAWA

C 204 Determination of Manganese Dioxide in Black Mix of Dry Battery, IChiro Muraki, TAKashi Tsu- 
Chid a, Kenichi Sinoda, TakaShi Hori and Mutsuo Aoshima

C 205 Studies on Active Materials of Lead-Acid Battery, HIROAKI HABA, Kiyoshi Ninomiya and TAKEO CHIKU

C 206 The Behavior of $\mathrm{pb}$ and $\mathrm{PbO}_{2}$ Electrodes in the Sulphuric Acid Solution. III, SATOSHI SEKIDO, Hideyuki IChimura and MASATARO FUKUDA

\section{Electronics and Materials for Electrical Industry}

C 207 Ionics of Solids Ionic Conduction of Perovskite Type Oxides, TAKEHIKO TAKAHASHI and HIROYASU IW A H A R A

C 208 Ionics of Solids --- $\mathrm{Ag}_{2} \mathrm{Se}-\mathrm{HgI}_{2}$ System, TAKEHIKO TAKAHASHI, Osamu Yamamoto and Katsumi KUW A B A R A

C 200 Hydrogen Current-Time Integrator, TAKUYA HATA and HIROMASA MATSIOKA

C 210 Emitter Dip Effect in Double Diffused Silicon Transistor, MASAO MaEda, Toyotaka Manabe and MASAAKI TANIMOTO

C 211 Magnetic Induced Oscillations in Germanium, MAKOTO MORIYAMA, KYOZO MATSUSHITA, TADAO MORI, YOSHIAKI MATSUI and SABURO TA KEMOTO

C 212 On the Properties of Anodic Tantalum Oxide Film Formed in the Solution of Phosphoric Acid with Phosphor-32 as a Tracer, YASUO
SeKi, Yoshio Hoshino and TaK UJI ITO

C 213 Reduction Process of $a \cdot \mathrm{Fe}_{2} \mathrm{O}_{3}$ Powders and its Magnetic Properties, YASUO IMAOKA, MINORU $\mathrm{S}_{\mathrm{A}} \mathrm{TO}$ and YASUSHí HOSHINO

C 214 Relation Between Semi-conducting Properties and Magnetic Properties of $\mathrm{Co}_{\mathrm{x}}, \mathrm{Fe}_{3-\mathrm{x}} \mathrm{O}_{4}$ Magnetic Properties of $\mathrm{Co}_{\mathrm{x}} \mathrm{Fe}_{3-\mathrm{x}} \mathrm{O}_{4}$ Polycrystals, YUKINOBU Kumashiro, MINORU SATO and YASUSHI HOSHINO

C 215 Magnetic Properties of Co-Ni Films Electrodeposited, SATOSHI TANA$\mathrm{KA}$, Minoru SATO and YASUSHI HOSHINO

C 216 Magnetic Recording Characteristics of Multi-Layer Co Films Electrodeposited, TATSURU NAMIKAWA, SATOS HI TANAKA and MINORU SATO

C 217 Electrical Properties of Silicon Dioxide, MASAO MAEDA and $\mathrm{T}_{\mathrm{E}}$ TSUSHI SAKAI

C 218 Zinc Sulphide Thin Films Prepared by Reactive Sputtering, MASAYASU TSUIKI and Yoshio Yoshida

C 219 The Electrical Properties of Pyrolytic Carbon Film, YoshikazU NA K AMOTO

C 220 Relationship Between Luminescence on Manganese and Copper in Zinc Sulfide Phosphors, $\mathrm{K}_{\mathrm{A}} \mathrm{TSUMI}$ TAKAGI and KENJI MASAgO

C 221 Photoconductivity in Mercuric Iodide, KUnio TAKAgI and HIROAKI KUSHIMA

C 222 On the Creeping Phenomenon of Selenium Photocell. II, HIDENORI MAEZ A W A 


\section{The 17th Meeting}

of

\section{Comité International de Thermodynamic ef de Cinétique Electrochimiques}

Tokyo and Kyoto, September 4-13, 1966

The 17th meeting of CITCE will be held in Tokyo and Kyoto, Japan in 1960 with the collaborations of the Electrochemical Society of Japan and the Chernical Society of Japan.

Sessions will be scheduled from September 4 to 9 in Tokyo on:
(a) General Themes:
(i) Fundamental Problems in corrosion, passivation, electro- deposition and battery.
(ii) Organic electrochemistry.
(b) Commision 1.
Electrochemical thermodynamics.
(c) Commision 2.
Electrochemical nomenclature and definitions.
(d) Commision 3.
Experimental method in electrochemistry
(e) Commision 4 .
Batteries.
(f) Commision 5 .
Corrosion.
(g) Commision 6.
Electroch enical kinetics.
(h) Commision 7 .
Electroch emistry of semi-conductors.
(i) Commision 8.
Electrochemistry of high temperature.
(j) Commision 9.
Organic electroch ernistry .

Discussion sessions will also be scheduled from September 12 to 13 in Kyoto on:
(a) Fused salts;
Properties of fused salts.
(b) Fuel cells;
Problems in fuel cell research.

Further informations and registration form will be announced on the official circular issued by CITCE. The circulars will be available from the Secretariat of National Organization Committee of the 17th Meeting of CITCE, c/o Industrial Chemistry Section, Faculty of Engineering, Tokyo Metropolitan University, 1-950, Fukazawa-cho, Setagaya-ku, Tokyo. 